\title{
STUDI PEMBUATAN BRIKET ARANG DARI TANAH GAMBUT SEBAGAI SOLUSI PRAKTIS PENGGANTI KAYU BAKAR
}

\author{
Oleh : \\ Henok Siagian $^{1)}$, Edi Suranta Ginting ${ }^{2)}$ \\ 1). Dosen Fisika Universitas Negeri Medan \\ 2). Mahasiswa Fisika Universitas Negeri Medan
}

\begin{abstract}
ABSTRAK
Tujuan Penelitian ini adalah : (1). Untuk membuat briket arang dari tanah gambut Lintongnihuta (2). Untuk mengetahui nilai kalor briket arang tanah gambut Lintongnihuta yang dibuat dengan variasi massa bahan perekat, lama pengeringan dan tekanan (3). dan Untuk mengetahui perbandingan nilai kalor briket arang gambut dengan nilai kalor standard Jepang. Bahan dasar pembuatan briket arang ini adalah tanah gambut yang berasal dari Lintongnihuta dengan memakai bahan perekat tepung tapioka. Cara pembuatannya, tanah gambut dibakar selama 5-6 jam di dalam drum pembakaran hingga menjadi arang kemudian didinginkan selama 8 jam dan setelah jadi arang diayak hingga ukuran 100 mesh. Metode pembuatan briket : Arang yang sudah diayak dicampur perekat adonan tepung tapioka dengan perbandingan (122,5: 2,5) gram ; $(120,0: 5,0)$ gram ; $(117,5: 7,5)$ gram, kemudian dicetak pakai mesin hidrolik dengan variasi tekanan 9 ton dan 7 ton, lalu dikeringkan di bawah sinar matahari dengan variasi 1 hari, 3 hari dan 5 hari. Setelah briket arang kering dilakukan pengujian nilai kalor dengan menggunakan kalorimeter bom. Hasil penelitian diperoleh bahwa : Nilai kalor briket arang tanah gambut Lintongnihuta yang dicampur perekat tepung tapioka dipengaruhi oleh variasi tekanan dan lama pengeringan. Semakin besar tekanan yang diberikan pada saat pencetakan briket semakin tinggi nilai kalornya dan semakin lama pengeringan briket semakin tinggi juga nilai kalornya. Nilai kalor tertinggi diperoleh pada perbandingan briket arang tanah gambut dengan perekat $(122,5: 2,5)$ gram dengan tekanan 9 ton dan lama pengeringan 5 hari sebesar $6712,54 \mathrm{kal} / \mathrm{gr}$. Nilai kalor briket arang tanah gambut Lintongnihuta memenuhi standar kalor briket Jepang 6000-7000 kal/gr. Berdasarkan penelitian ini disimpulkan bahwa briket arang tanah gambut Lintongnihuta dapat dipakai sebagai pengganti kayu bakar untuk keperluan rumah tangga.
\end{abstract}

Kata kunci : Briket arang, tanah gambut, nilai kalor, kayu bakar

\section{Latar Belakang}

Gambut merupakan salah satu penyusun bahan bakar yang terdapat di bawah permukaan tanah. Gambut mempunyai kemampuan dalam menyerap air sangat besar, karena itu, meskipun tanah di bagian atasnya sudah kering, di bagian bawahnya tetap lembab dan bahkan relatif masih basah karena mengandung air. Sehingga sebagai bahan bakar bawah permukaan ia memiliki kadar air yang lebih tinggi daripada bahan bakar permukaan (serasah, ranting, log) dan bahan bakar 
atas (tajuk pohon, lumut, epifit). Saat musim kemarau, permukaan tanah gambut cepat sekali kering dan mudah terbakar, dan api di permukaan ini dapat merambat ke lapisan bagian bawah/dalam yang relatif lembab. Oleh karenanya, ketika terbakar, kobaran api tersebut akan bercampur dengan uap air di dalam gambut dan menghasilkan asap yang sangat banyak.

Tanah gambut terbentuk dari akumulasi sisa-sisa tanaman purba yang mati dan sebagian mengalami perombakan, mengandung minimal 12 18\% C-organik dengan ketebalan minimal $50 \mathrm{~cm}$. Secara taksonomi tanah disebut juga sebagai tanah gambut, Histosol atau Organosol bila memiliki ketebalan lapisan gambut $>40 \mathrm{~cm}$, bila bulk density $>0,1 \mathrm{~g} / \mathrm{cm}^{3}$.

Luas lahan gambut di Indonesia diperkirakan 13 juta ha yang dibedakan ke dalam gambut dangkal, sedang, dan sangat dalam. Lintongnihuta adalah salah satu desa yang memliliki potensi tanah gambut. Desa ini terletak di kecamatan Doloksanggul Kabupaten Humbang Hasundutan. Tiga orang doktor dari Institut Pertanian Bogor (IPB) masing-masing Dr. Ir. Istomo, Dr. Ir. Imam Wahyudi dan Dr. Ir. Sobir pernah berkunjung ke Kabupaten Humbang Hasundutan untuk meneliti tanah gambut di Desa Nagasaribu Lintongnihuta dan di Aek Nauli II Kecamatan Doloksanggul. Selain melakukan penelitian secara ilmiah juga meneliti apa manfaat dari tanah gambut dan dampak negatif bagi masyarakat sekitar jika terus dieksploitasi (Silaban, 2006).

Salah satu cara untuk mengoptimalkan potensi gambut adalah memanfaatkannya sebagai bahan baku dalam pembuatan briket yang dapat dijadikan sebagai bahan bakar alternatif. Pembuatan briket arang aktif dari tanah gambut dapat dilakukan dengan cara penambahan perekat tapioka dimana bahan baku diarangkan terlebih dahulu, dihaluskan, dicampur perekat kemudian dicetak selanjutnya dikeringkan.

Briket arang yaitu arang yang mempunyai bentuk tertentu yang kerapatannya tinggi dan dapat digunakan untuk keperluan sehari-hari sebagai bahan bakar alternatif. Pada pembuatan briket perlu diperhatikan nilai kalor bakar, kadar air, kerapatan dan kadar abu. Untuk mendapatkan briket dapat melalui proses penekanan terhadap campuran arang dan perekat yang kemudian dilakukan proses pemanasan terhadap briket tersebut pada temperatur dan waktu tertentu (Helena, 2002).

Penggunaan perekat dan pemberian tekanan pada umumnya akan memperbaiki beberapa sifat fisis dan kimia briket arang yang akan dihasilkan, dengan kombinasi terbaik antara perekat dengan tekanan dilihat dari sifat fisis dan kimia briket arang yang berorientasi lebih pada sifat kalor bakar yang dihasilkan dengan bahan baku serasah daun A. mangium terdapat pada perekat 7,5 \% dengan massa tekanan sebesar 9 ton. (Defirsa, 2001). Hasil penelitian sebelumnya juga menunjukkan bahwa nilai kalor briket gambut pada perbandingan gambut dengan perekat tepung kanji (98: 2)\% pada massa tekanan 7 ton sebesar $6419,24 \mathrm{kkal} / \mathrm{kg}$ (Sitorus, 2008).

Berdasarkan uraian di atas maka permasalahan yang ingin dicari jawabannya dalam penelitian ini adalah : 1) Bagaimana pengaruh variasi massa bahan perekat, lama pengeringan dan tekanan terhadap nilai kalor briket arang tanah gambut Lintongnihuta 2). Berapa perbandingan nilai kalor briket arang tanah gambut Lintongniguta dengan nilai kalor standard Jepang 3). Apakah 
briket arang yang dihasilkan dapat digunakan sebagai solusi pengganti kayu bakar?

\section{Metode Penelitian}

Penelitian dilaksanakan di laboratorium Fisika, Jurusan Fisika FMIPA Universitas Negeri Medan dan Laboratorium Penelitian Pendidikan Teknologi Kimia Industri Medan. Peralatan yang digunakan dalam penelitian ini adalah: Gelas Ukur, Cetakan Briket, Mesin Hydraulics, Jangka Sorong, Neraca Analitik, Drum tempat Pembakaran, Termometer, Cawan Porselin, Alat Penjepit, Batang Pengaduk, Kalorimeter Bom, Stopwatch, Ayakan, Erlenmeyer. Bahan-bahan yang digunakan dalam penelitian ini adalah: Arang aktif, Tepung Tapioka, dan tanah gambut Aquades

\section{Prosedur Penelitian}

\section{Pembuatan arang aktif}

Proses pembuatan arang aktif tanah gambut dimulai dengan memasukkan tanah gambut ke dalam drum pembakaran. Selanjutnya dilakukan pembakaran selama kurun waktu 5-6 jam. Setelah proses pembakaran tanah gambut selesai, drum pembakaran ditutup dan diberi cerobong asap. Selanjutnya drum pembakaran dibiarkan selama kurang lebih 8 jam hingga dingin. Setelah dingin, drum dibuka dan selanjutnya dilakukan pemisahan arang aktif tersebut dari abu, kemudian arang aktif diayak dengan menggunakan ayakan 100 mesh untuk mendapatkan arang yang halus.

\section{Pencampuran Bahan Perekat}

Bahan perekat yang digunakan adalah tepung tapioka dengan perbandingan campuran antara perekat dengan arang aktif tanah gambut (dalam ukuran gram) yaitu : $(2,5: 122,5) ;(5,0$ :
$120,0) ;(7,5: 117,5)$. Penggunaan bahan perekat bertujuan untuk menarik air dan membentuk tekstur yang padat atau mengikat dua substrat yang akan direkat.

\section{Pembuatan Briket Arang Tanah Gambut}

Proses pembuatan briket dari bahan baku tanah gambut dilakukan dengan mencampur arang aktif tanah gambut dengan perekat tepung tapioka sesuai dengan perbandingan yang telah ditetapkan dan diaduk hingga adonan homogen. Selenjutnya Adonan dimasukkan ke dalam cetakan yang berbentuk silinder dengan diameter 5 $\mathrm{cm}$ dan tinggi $10 \mathrm{~cm}$, kemudian ditekan menggunakan Hydrolic Machine dengan variasi tekanan 7 ton dan 9 ton. Sampel yang sudah tercetak dikeluarkan dari cetakan dan dikeringkan di bawah sinar matahari. Penjemuran sampel bervariasi, yaitu selama 1 hari, 3 hari, dan 5 hari.

\section{Teknik Analisis Data}

Penelitian ini, proses pemadatan dilakukan dengan menggunakan Hydrolic Machine, tekanan yang diberikan dalam satuan ton yaitu 2,54 $\pm 0,25 P a$. Tetapi satuan ton dikonversi ke dalam satuan pascal melalui persamaan berikut :

$$
\mathbf{P}=\frac{\mathbf{F}}{\mathrm{A}}
$$

dengan :

$\mathrm{P}=$ tekanan $(\mathrm{Pa})$

$\mathrm{F}$ = gaya $(\mathrm{N})$

A $=$ luas penampang $\left(\mathrm{m}^{2}\right)$

Besarnya $\mathrm{F}$ dihitung dengan :

$\mathrm{F}=\mathrm{m} \cdot \mathrm{g}$

dengan :

$\mathrm{F}$ = gaya $(\mathrm{N})$

$\mathrm{m}=$ massa $(\mathrm{kg})$

$\mathrm{g}=$ percepatan gravitasi bumi $\left(\mathrm{m} / \mathrm{s}^{2}\right)$ 
Karena cetakan berbentuk silinder, maka luas penampangnya adalah :

$$
A=\pi r^{2}
$$

Jika pers. (2) dan (3) disubstitusi ke pers.(1) diperoleh :

$$
P=\frac{\mathbf{m} \cdot \mathbf{g}}{\pi r^{2}}
$$

\section{Pengujian Nilai Kalor Briket}

Kalor merupakan suatu kuantitas atau jumlah panas baik yang diserap maupun dilepaskan oleh suatu benda. Nilai kalor diperoleh dengan menggunakan kalorimeter bomb. Langkah-langkah pengujian kalor bakar dengan menggunakan kalorimeter bomb sebagai berikut: 1) Menimbang massa briket sebanyak 1 gram dengan neraca analitik, 2) Cawan yang berisi briket ditempatkan pada penutup bomb yang ditutup dengan kuat setelah ring $\mathrm{O}$ dipasang. 3) Oksigen diisikan ke dalam tabung bomb dengan tekanan 25 bar dan ditempatkan ke dalam tabung bomb kalorimeter yang telah berisi air. 4) menghidupkan elektromotor dihidupkan dan alat pengaduk air serta mencatat temperatur air. 5) Alat penyala dihidupkan dan mencatat temperatur akhir air pendingin setelah 5 menit dari mulainya penyalaan.

Setelah pengujian briket dengan kalorimeter bom dilakukan, maka diperoleh suhu awal dan suhu akhir dari masing-masing sampel briket tanah gambut. Jadi nilai kalor masing-masing sampel dapat dihitung dengan :

$$
H=\frac{W \times T-E_{1}-E_{2}}{M}
$$

dengan :

$\mathrm{H}=$ heat of combustion in calories per gram

$\mathrm{W}=$ energy equivalent of calorimeter in calories per degree centigrade $\left(2325 \mathrm{cal} /{ }^{0} \mathrm{C}\right)$

$\mathrm{M}=$ mass of standard sample in grams (1 gr)

$\mathrm{T}=$ corrected temperature rise in degrees centigrade

$E_{1}=$ correction for heat of formation of nitric acid in calories

$E_{\mathbf{2}}=$ correction for heat of combustion of firing wire in calories

\section{Hasil Penelitian Dan Pembahasan 1.Hasil Penelitian}

Berikut ini adalah nilai kalor masing-masing sampel dihitung dengan

\begin{tabular}{|c|c|c|c|c|c|}
\hline \multirow[b]{2}{*}{ No } & \multicolumn{2}{|c|}{ Massa (gram) } & \multirow{2}{*}{$\begin{array}{c}\text { Lama } \\
\text { Pengeringan } \\
\text { (hari) }\end{array}$} & \multicolumn{2}{|c|}{ Nilai Kalor (kal/gr) } \\
\hline & $\begin{array}{c}\text { Arang } \\
\text { Gambut }\end{array}$ & $\begin{array}{l}\text { Perekat } \\
\text { Tapioka }\end{array}$ & & $\begin{array}{c}\text { Tekanan } 7 \\
\text { ton }\end{array}$ & Tekanan 9 ton \\
\hline \multirow{3}{*}{1} & \multirow{3}{*}{122,5} & \multirow{3}{*}{2,5} & 1 & 3457,54 & 3690,04 \\
\hline & & & 3 & 3480,79 & 6201,04 \\
\hline & & & 5 & 5410,54 & 6712,54 \\
\hline \multirow{3}{*}{2} & \multirow{3}{*}{120,0} & \multirow{3}{*}{5,0} & 1 & 3457,54 & 3457,54 \\
\hline & & & 3 & 4992,04 & 5410,54 \\
\hline & & & 5 & 5898,79 & 6247,54 \\
\hline \multirow{3}{*}{3} & \multirow{3}{*}{117,5} & \multirow{3}{*}{7,5} & 1 & 3387,79 & 3527,29 \\
\hline & & & 3 & 5038,54 & 4829,29 \\
\hline & & & 5 & 5038,54 & 5085,04 \\
\hline
\end{tabular}
pers.(5) hasilnya sebagai berikut:

Tabel 1. Hasil Perhitungan Nilai Kalor Briket

Dari data pada tabel 3 di atas dibuat grafik hubungan antara jumlah perekat terhadap energi briket pada tekanan 7 ton (grafik 1) dan grafik hubungan 
antara jumlah perekat terhadap energi briket pada tekanan 9 ton (grafik 2).
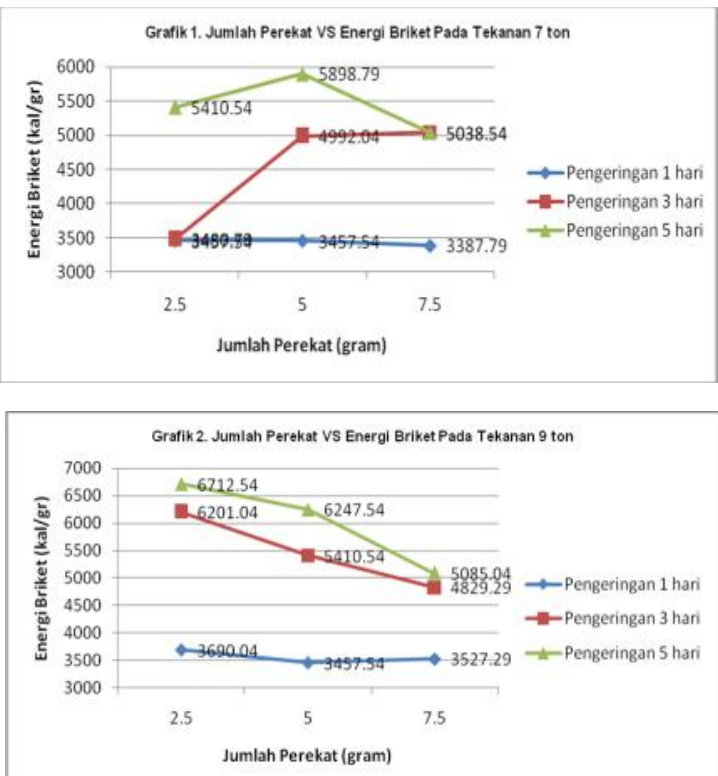

Gambar 1. grafik hubungan antara jumlah perekat terhadap energi briket.

\section{Pembahasan}

\subsection{Hubungan Massa Perekat}

Terhadap Nilai Kalor Briket.

Perekat tepung tapioka berfungsi untuk merekatkan partikel-partikel zat dalam arang tanah gambut sehingga pada proses pencetakannya arang tanah gambut bisa dibentuk sesuai dengan cetakan yang digunakan. Hasil penelitian menunjukkan bahwa nilai kalor briket menurun jika massa perekat bertambah, hal ini dapat dilihat pada grafik 2. Semakin besar massa tepung tapioka yang ditambahkan nilai kalor briket menjadi semakin kecil karena semakin besar massa tepung tapioka yang diberikan menyebabkan semakin besar pula kadar air yang terkandung pada briket karena adanya penambahan air yang berasal dari tepung tapioka. Berdasarkan grafik di atas nilai kalor briket paling besar terdapat pada massa perekat 2,5 gr yaitu $6712,54 \mathrm{kal} / \mathrm{gr}$ dan nilai kalor briket terkecil terdapat pada massa perekat 7,5 gram yaitu 3387,79 $\mathrm{kal} / \mathrm{gr}$.

\subsection{Hubungan Antara Lama Pengeringan Terhadap Nilai Kalor Briket}

Fungsi pengeringan briket dengan panas matahari adalah untuk memperoleh briket yang kering dan memiliki kadar air yang rendah. Hasil penelitian menunjukkan bahwa terdapat hubungan antara lama pengeringan terhadap nilai kalor briket tanah gambut. Nilai kalor semakin besar dengan variasi waktu pengeringan yang makin lama. Hal ini dapat dilihat pada tabel 4 di bawah ini.

Tabel 2. Nilai kalor briket berdasarkan lama pengeringan

\begin{tabular}{|c|c|l|l|}
\hline \multirow{2}{*}{ No. } & \multirow{2}{*}{$\begin{array}{c}\text { Lama } \\
\text { Pengeringan } \\
\text { (hari) }\end{array}$} & \multicolumn{2}{|c|}{ Kalor $(\mathrm{kal} / \mathrm{gr})$} \\
\cline { 3 - 4 } & $\mathbf{7}$ ton & $\begin{array}{l}\text { Tekanan } \\
9 \text { ton }\end{array}$ \\
\hline 1 & 1 & 3457,54 & 3690,04 \\
\hline 2 & 3 & 3480,79 & 6201,04 \\
\hline 3 & 5 & 5410,54 & 6712,54 \\
\hline
\end{tabular}

Semakin lama waktu pengeringan briket, mengakibatkan menurunnya kadar air yang terkandung dalam briket sebagai akibat pemanasan. Berkurangnya air yang terdapat di dalam briket akan menyebabkan kalor yang dihasilkan dari pembakaran briket semakin besar. Nilai kalor paling besar jika lama pengeringan lima hari yaitu sebesar 6712, $54 \mathrm{kal} / \mathrm{gr}$, sedangkan nilai kalor yang paling kecil jika lama pengeringan satu hari yaitu 3457,54 $\mathrm{kal} / \mathrm{gr}$.

\subsection{Hubungan Antara Massa Tekanan Terhadap Nilai Kalor Briket \\ Dari tabel 4 di atas diperoleh data bahwa nilai kalor briket}


berdasarkan perbandingan variasi tekanan pada pencetakan briket adalah bahwa tekanan mempengaruhi nilai kalor briket arang tanah gambut, dimana nilai kalor semakin besar jika tekanan semakin besar. Hal ini disebabkan dengan besarnya tekanan massa pada saat pencetakan kerapatan briket arang tanah gambut semakin tinggi.

\subsection{Laju Pembakaran Briket}

Laju pembakaran briket adalah kecepatan briket habis sampai menjadi abu dengan berat tertentu. Laju pembakaran briket diuji dengan sampel perbandingan massa arang dan perekat (122,5 gram : 2,5 gram) dengan tekanan 9 ton pada pengeringan 5 hari. Laju pembakaran briket bahan baku adalah 0,045 gram/detik, untuk penambahan 0,5 gram minyak goreng laju pembakaran briket menjadi 0,041 gram/detik, dan untuk penambahan 0,5 gram kalium klorat laju pembakaran briket menjadi 0,038 gram/detik. Data di atas menunjukkan bahwa dengan penambahan minyak goreng dan kalium klorat mempengaruhi laju pembakaran briket arang tanah gambut.

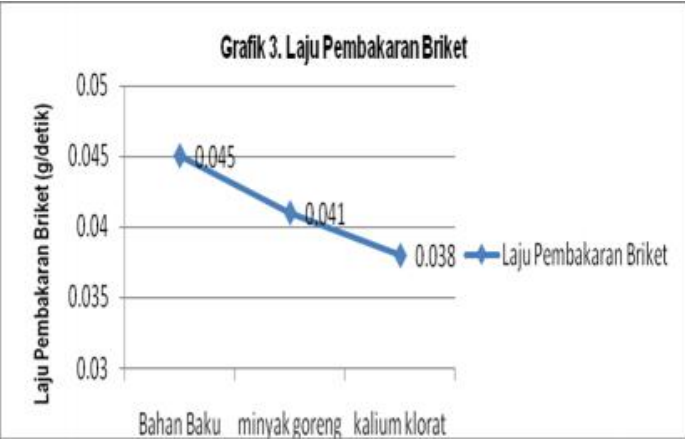

Gambar 2. grafik laju pembakaran briket

Berdasarkan grafik di atas dengan penambahan minyak goreng atau kalium klorat pada briket maka laju pembakaran briket semakin kecil, artinya bahwa pada saat briket dibakar waktu yang dibutuhkan untuk pembakaran briket sampai habis semakin lama dibandingan dengan briket tanpa ada tambahan.

\section{Kesimpulan Dan Saran}

Berdasarkan hasil penelitian dan pembahasan yang telah dilakukan, maka disimpulkan :

1. penambahan variasi massa perekst dapat menurunkan nilai kalor briket. Semakin besar massa tepung tapioka yang ditambahkan nilai kalor briket menjadi semakin kecil karena semakin besar massa tepung tapioka yang diberikan menyebabkan semakin besar pula kadar air yang terkandung pada briket karena adanya penambahan air yang berasal dari tepung tapioka. Nilai kalor briket paling besar terdapat pada massa perekat 2,5 gr yaitu $6712,54 \mathrm{kal} / \mathrm{gr}$ dan nilai kalor briket terendah pada massa perekat 7,5 gram yaitu $3387,79 \mathrm{kal} / \mathrm{gr}$.

2. Semakin lama waktu pengeringan briket, mengakibatkan menurunnya kadar air yang terkandung dalam briket. Berkurangnya air yang terdapat di dalam briket akan menyebabkan kalor yang dihasilkan dari pembakaran briket semakin besar. Nilai kalor paling besar jika lama pengeringan lima hari yaitu sebesar 6712, $54 \mathrm{kal} / \mathrm{gr}$, sedangkan nilai kalor yang paling kecil jika lama pengeringan satu hari yaitu $3457,54 \mathrm{kal} / \mathrm{gr}$.

3. Tekanan mempengaruhi nilai kalor briket arang tanah gambut, dimana nilai kalor semakin besar jika tekanan semakin besar. Hal ini disebabkan dengan besarnya tekanan massa pada saat pencetakan kerapatan briket arang tanah gambut semakin tinggi.

4. Nilai kalor briket gambut yang memenuhi standar nilai kalor 
Jepang adalah terdapat pada perbandingan arang gambut dengan perekat (122,5 gram : 2,5 gram) pada tekanan 9 ton dan lama pengeringan 5 hari dengan nilai kalornya $6712,54 \mathrm{kal} / \mathrm{gr}$.

Adapun hal yang disarankan untuk penelitian selanjutnya adalah:

1. Untuk proses pencetakan briket gambut perlu menambah variasi tekanan diatas 9 ton sehingga diperoleh hubungan tekanan terhadap nilai kalor briket gambut yang lebih baik.

2. Perlu dilakukan penelitian dengan menggunakan bahan perekat yang lain dan menambahkan bahan kimia lain untuk mendapatkan nilai kalor briket yang optimal.

\section{Daftar Pustaka}

Capah, A.G., (2007), Pengaruh Konsentrasi Perekat dan Ukuran Serbuk Terhadap Kualitas Briket Arang dari limbah Pembalakan Kayu mangium (Acacia mangium Willd), Skripsi, Fakultas Pertanian, Universitas Sumatera Utara, Medan

Helena, M.T., (2002), Pemanfaatan Debu karbon yang Dibuang dari Pabrik Penangkalan (Roading Plant) pada Peleburan Aluminium Menjadi Briket, Skripsi, PTKI, Medan

Masturin, A., (2002), Sifat Fisik dan Kimia Briket Arang dari Campuran Arang Limbah Gergajian Kayu, Skripsi, Fakultas Kehutanan, Institut Pertanian Bogor, Bogor
Sinukaban, S., (2008), Campuran Briket Gambut dengan tapioka sebagai perekat untuk menghasilkan energy pengganti minyak tanah, Skripsi, FMIPA, Unimed, Medan

Silaban (2006), http://www.net/2006/10/11/Penga mbilan-tanah-gambut-di-

lintongnihuta/

(accessed Desember 2012)

Sitorus, E., (2008), Pengaruh Variasi Tekanan Terhadap Nilai Kalor Briket Gambut, Skripsi, FMIPA, Unimed, Medan

Sutiyono, Pembuatan Briket Arang dari Tempurung Kelapa dengan Bahan Pengikat Tetes Tebu dan Tapioka, Jurnal Kimia dan Teknologi vol $10: 217-222$ 